\title{
1. Nigeria: defying the resource curse
}

\section{Inge Amundsen}

Nigeria has recently challenged one of the stronger hypotheses of the 'resource curse' theory; that oil wealth tends to block democratic transitions. According to Andersen and Ross (2014: 993), many studies have found that authoritarian countries with more oil wealth (that is, oil-dependent countries) are less likely to transition to democracy. For instance, Ross (2012) argues strongly that oil hurts democracy, and Andersen and Aslaksen (2013: 90) find a positive relationship between oil and political survival in non-democracies.

Now, most of the literature on the resource curse has regarded Nigeria as a quintessential example of a resource cursed country (see for instance Collier and Hoeffler 2001; Sachs and Warner 2001; Auty 1993; Mähler 2010). However, Nigeria made a remarkable democratic transition with the March 2015 general elections.

There are several explanations of how Nigeria managed to make this move and defy the deep structural conditions of the resource curse, which should, theoretically, hinder any democratic transition. In this chapter, I will argue that the main explanation to this puzzle was a slow but assured increase in the quality of several government institutions of checks and balances. In addition, the opposition (now ruling) party bridged the north-south divide, certain personalities played a positive role at important junctures, and a new generation of Nigerians refused to play by the old rules.

\section{THE RESOURCE CURSE}

It is a paradox that some countries bestowed with rich natural resources tend to decline in terms of economic growth, and in terms of human and political development. Economists have for some time discussed this resource curse and searched for explanations to why some countries with rich endowments of resources seem to have unexpectedly little long-term 
growth and diversification (see for instance Sachs and Warner 2001; Gylfason 2001; Humphreys et al. 2007).

One of the stronger economic explanations to the curse is that an increase in revenues from natural resources appreciates the exchange rate and makes other sectors less competitive. In addition, volatile commodity prices are disruptive. In particular, the negative price effect and a decline in investments 'crowds out' manufacturing and agriculture. This is the so-called 'Dutch disease' (Humphreys et al. 2007: 5-6).

Some of the literature also highlights political and institutional factors: according to Heller, the analysis must shift to political institutions to explain the resource curse (Heller 2006: 24), and according to Mehlum et al. (2006: 1119), the main difference between success and failure is in the quality of institutions. Basically, the rents generated from mineral extraction and other easily accessible resources can either be channelled into the productive economy, or be captured by the ruling elite for personal enrichment, status gain, and power purposes.

Political scientists working on the theory thus emphasize that an abundance of natural resources tend to produce not only weak economic growth but also more entrenched authoritarian rule. This is because natural resource windfalls not only lead to an overexpansion of the public sector, patronage, and clientelism (Robinson et al. 2005: 464); resource rents also provide power-holders with both the incentives and the means to hold on to power (Amundsen 2014: 172). Typically, oil wealth enables regimes to spend more on security and repression forces (Ross 2001: $335)$.

It seems, however, that a country is cursed only when it becomes dependent on, and enriched by, export of natural resources before accountable and democratic state institutions are established and consolidated. All the 'resource blessed' countries (like Norway, Australia, Canada, Brazil and Malaysia) were established democracies before the export boom set in. In fact, over the last three decades, no resource-rich and export-dependent authoritarian country has democratized. Perhaps Venezuela is an exemption (to the extent you believe 'Chávism' is democratic), but a closer look at the oil-rich Middle Eastern and African countries makes the point. The oil-rich Middle East has not democratized, Iran and Iraq remain unfree, and among the petroleum exporters in Africa south of the Sahara, we find Angola and Equatorial Guinea with presidents in office for over 35 years, and Gabon and the Democratic Republic of the Congo are countries run to a large extent as 'family businesses', with a few families in control of the government and the bulk of the economy. 
Nigeria is, unexpectedly, the only example of an authoritarian and heavily oil-dependent regime that has made what seems to be a fullyfledged transition to democracy, after it became oil export-dependent.

\section{NIGERIA'S CURSE}

Nigeria is an archetypical 'oil nation', a mono-economy in which oil dwarfs every other economic sector. The sale of crude oil totalled 77 billion USD in 2014 and made up about 75 per cent of Nigeria's government revenues. Since the 1970s, oil has accounted for 90-95 per cent of all foreign exports and 70-85 per cent of all government revenues.

Nigeria is a resource cursed country according to most of the literature. Radon says, 'Nigeria has been bedevilled by the natural resource curse and has witnessed a significant decrease in living standards, unfathomable corruption, and societal strife' (in Humphreys et al. 2007: 94). Shaxson (2007: 18) argues that the 'crowding out' effect in Nigeria during the oil-boom years produced a 60 per cent decline in agricultural output and 'plunged tens of millions of people into poverty'.

The economic indicators of the resource curse in Nigeria are, first, the fact that the people of Nigeria remain as poor today as before oil (that is, before the early 1970s and a production of over 2 million barrels of crude oil a day). In 2014, almost 100 million Nigerians (60.9 per cent) were living on less than USD 1 a day (that is, in 'absolute poverty'). In 1980, the figures were only 17.1 million (and 30 per cent) (National Bureau of Statistics). In other words, the level of poverty has risen substantially in both absolute and relative terms.

A second indicator is the low level of economic diversification. In the wake of the oil boom of the 1970s, agriculture and manufacturing fell from 44.2 and 12.4 to 24.7 and 4.8 per cent of GDP, respectively (Usman 2014: 4). Although Nigeria has been among the ten fastest growing countries in the world in the 2000s, a recent report on economic transformation argues that Nigeria is among the least transformed countries in Africa. It scores zero on a combined index of diversification, export competitiveness, productivity, technology upgrading, and this poor showing 'reflects its extreme dependence on producing and exporting oil' (ACET 2014: 32-33).

However, there are a few signs that economic growth in Nigeria is moving beyond petroleum extraction. Both export earnings and government revenues from non-oil sectors have been slowly but steadily 
increasing since around 2006, with Lagos as the biggest non-oil production area. The so-called middle class now constitutes roughly 30 per cent of the population in Lagos, and the proportion is increasing (Amundsen 2010: 7). Lagos (and to some extent Kaduna, Cross River and Bayelsa states) are also reform-oriented with a relatively better institutional and financial control of federal transfers and locally generated revenues (Amundsen 2010: 14).

The political indicators of the resource curse in Nigeria are the civil war and the many dictatorships the country has seen since independence. The Biafra secessionist war from 1967 to 1970 is often explained as a conflict over access to natural resources, and the military regimes from 1966 to 1979 (with a short civilian interlude from 1979 to 1983), and again from 1983 to 1999 , are the basic political indicators. In addition, the transition to civilian rule in 1999 can be regarded as less than a full democratic transition as it was a hand-over from the military to a former military general, Olesegun Obasanjo, and the military-dominated PDP, and this party continued to rule until 2015 although with different presidents.

The current Boko Haram insurgency in the northeastern parts of the country has also been blamed on the resource curse, not least because of the extreme income inequalities between the north and the south. 'Boko Haram represents the resource curse's disastrous end game' (Goldfond 2015) and the 'situation is particularly dire in the far north. Frustration and alienation drive many to join "self-help" ethnic, religious, community or civic groups, some of which are hostile to the state. It is in this environment that the group called Boko Haram [...] emerged' (International Crisis Group 2014: 1).

At the same time, the oil revenues combined with systemic corruption, embezzlement, and capital flight has created huge benefits to the ruling elite. Private enrichment is glaring, with former president Abacha embezzling USD 2-5 billion during his reign (TI 2004: 1), and at least three out of the five Nigerians on Forbes' 2015 list of billionaires have their wealth from combining their political influence and connections with oil revenues.

The 'privatization' of some of the government oil revenues has taken many forms. One is the establishment of private oil companies that get government contracts and partnerships with foreign oil companies, with the help of government connections. Another is the banking sector, which has a long history of unsecured loans and embezzlement involving politically well-connected people, bailed out by the government (TI 2009: 201). 
Yet another 'big hole' includes Nigeria's fiscal federalism, where the 36 states are responsible for about half of all government spending (some estimates say up to 60 per cent) (Amundsen 2010: 21), and where the leakages are huge with rampant power abuse and embezzlement. The leakages also include corruption in the national procurement systems. According to the World Bank's Country Procurement Assessment Report (CPAR) for 1999, 60 per cent of the money spent by the government was lost to underhand practices. Although the situation has improved through better legislation, the collusion between the (former) ruling party dignitaries, government and military officials, and politicians has enabled a massive 'privatization' of public funds. Corruption has been so pervasive in Nigeria that it has turned public service into a kind of criminal enterprise (HRW 2011: 1).

Nigeria's government institutions have been notoriously weak. According to the Worldwide Governance Indicators, the level of government effectiveness, regulatory quality and rule of law is low. It is low even compared with the sub-Saharan African average, and it has remained so over many years (with perhaps a little improvement in the rule of law over the last few years) (World Bank Institute 2013).

The Nigerian National Petroleum Corporation (NNPC), for instance, is not transparent, and one of the 'biggest and most chaotic' of the world's national oil companies, 'and a mess: a conventional business analysis would effortlessly rank NNPC as one of the world's top mismanaged firms' (Soares de Oliveira 2007: 93). It is also 'one of the most difficult agencies of [the] government to tackle because of vested interests of very powerful people in the country' (Gboyega et al. 2011: 8).

\section{NIGERIA DEFYING THE CURSE}

Nigeria nevertheless made a democratic transition with the elections in April 2015 and a peaceful and constitutional transfer of power from President Jonathan and the People's Democratic Party (PDP), the ruling party since 1999, to President Buhari and his newly formed opposition alliance, the All Progressives Congress (APC).

The fact that Nigeria has defied the deep structural conditions of the resource curse and managed a democratic transition in 2015 is, to some extent, explained by the recent fall in oil prices and the ensuing massive fall in government revenues and possibilities for patronage prior to the elections. However, various political ecology explanations offer a deeper understanding. The costs and benefits of resource extraction - and the following environmental damages - have been distributed very unequally, 
creating and breaking up political alliances between favoured and disfavoured groups.

\section{BRIDGING THE NORTH-SOUTH GAP}

The on-shore oil production in the southeastern Niger-delta region has traditionally been a stronghold of the regime, together with Abuja (the federal capital) and some eastern parts of the country. However, the on-shore oil production in the Delta region has destroyed the livelihoods of the population of the area. It has led to forced displacements, created massive environmental damage, destroyed fishing waters and farmland, and caused health damage due to oil spills, gas flaring and contaminated water (see for instance Watts 2004; HRW 2005; Soares de Oliveira 2007: 243; Amundsen 2010: 12-13; Mähler 2010: 16).

Therefore, despite their ethnic and historic affiliations with President Jonathan, and despite government largesse in terms of co-opting and bailing out the many protest movements in the area, the Delta population turned out to vote for Jonathan in much fewer numbers than expected. Most observers believed Jonathan had complete control of the vote in the Delta region (Edozien 2015), but former militants and the MEND insurgency group openly supported Buhari and the APC (SaharaReporters 2015).

The northern part of Nigeria is the poorest part of the country, and it has suffered droughts, soil degradation, and conflicts over access to land. The northern population, counting for roughly a half, has also lagged behind in terms of income, education, security, and political voice, and it has been a breeding ground for opposition and protest. Not only is it the home area of the terrorist organization Boko Haram, the north voted massively for Buhari and the opposition alliance.

The natural resource-poor southwest, with the biggest city and economic capital Lagos, has avoided the attention of the government for good and for bad. With no natural resources to exploit, it has gone through a 'normal' path of development, and become the industrial and trade hub of the country, far more advanced, economically and politically, than other parts of the country.

In February 2013, the party that dominated Lagos for a long time joined forces with the party that dominated the northern parts of Nigeria, and formed the APC. Thus, with the southwest joining forces with the north in this alliance, the opposition (now ruling party) bridged the north-south division and unseated the incumbent, President Jonathan, and ended the 16 years of rule of the PDP. 


\section{BOLSTERING THE INSTITUTIONS}

A political science rule-of-thumb says that democracy is consolidated when the opposition party (alliance) has won twice, and the government has consequently stepped down twice, peacefully and constitutionally. Democratic procedures can then be said to be fully respected, and democracy to be the 'only game in town'.

Nigeria is almost there. Although elections established a civilian government in 1999, the first elected civilian president, Obasanjo, was a former military ruler, and the ensuing elections (all until the 2015 elections) were heavily rigged and continuously returned the ruling party to power. Thus, the elections of head of state and government were more of a party- and ruling elite internal affair.

The 2015 elections were the most expensive but also the most peaceful, the least rigged, and the most consequential in Nigeria's history. For the first time since independence, political power was transferred peacefully from one political party to another, because of free and fair elections. This has (hopefully) established a new pattern, where change in government is possible through elections.

This happened much thanks to the Independent National Electoral Commission (INEC) and its Chairman, Attahiru Jega. The INEC has now established itself as an institution able to deliver credible elections that can sustain Nigeria's nascent democracy. The importance of Jega's integrity and professionalism is unquestioned, and innovative measures like the INEC half hour, a thirty-minute public enlightenment television programme, illustrates the institution's outreach and credibility.

The development of a number of other institutions of checks and balances, insight and control are also significant, bearing witness to a slowly increasing constitutionalism and institutionalization of Nigerian politics.

One is the Economic and Financial Crimes Commission (EFCC), the main anti-corruption institution in Nigeria. The EFCC gained much influence and respect, especially under former commissioner Nuhu Ribadu, although the subsequent lack of substantial and visible success coupled with political wing-clipping under President Jonathan weakened the institution. Yet, knowledge (and condemnation) of corruption has intensified, and the EFCC has made important progress in recovering assets that are the proceeds of crime (HRW 2011).

Besides, Nigeria adopted a Freedom of Information Act in 2011, the press is 'partly free', it is a 'compliant country' of the Extractive Industries Transparency Initiative (EITI), and civil society has improved in terms of competence, activity, and outreach since 1999. 
Although the Nigerian constitution seeks to divide power, modelled after the American constitution, the President (executive branch) is still constitutionally dominant, with a strong centralization of financial and political power in the office of the presidency. Informal practices like clientelism, patronage and political favouritism not only adds to this; the informal exercise of power by Nigeria's political oligarchy often exerts more control over daily life than do formal institutions.

The Parliament is weak, and the senior politicians of the Senate and House of Representatives are some of the biggest cats feeding on the system. It is not a change-oriented institution; it is a 'pork barrel' of spoils distribution, favouritism, and politically motivated financial and material inducements and advantages (Amundsen 2010: 18). The judiciary with the Supreme Court is also rather ineffective as a political counter-power, although it has gained some strength lately, according to the governance indicators cited above. This improvement has a lot to do with a more independent nomination process of Supreme Court judges, and a few cases in which the judiciary has asserted its independence.

Some of Nigeria's institutions of checks and balances have received donor support and funding, although Nigeria's vast oil wealth means that it is not dependent on donor funds, and donors have consequently much less influence than elsewhere in Africa. (For instance, USAID's budget for democracy and governance in Nigeria in 2014 was approximately USD 2.7 million, election support excluded, which is roughly what three Nigerian gubernatorial candidates could legally spend on their election campaigns.)

Yet, some of the foreign interventions have been strategic and symbolically significant. For instance, support for the Election Commission has helped it maintain its independence and withstand government pressures (the UK alone provided USD 5.2 million to support the 2015 elections, including INEC). The former EFCC leader received personal support by Norad (the Norwegian Agency for Development Cooperation) through its corruption hunters network, and some legal reforms have been pushed through with the help of EITI and the World Bank. A large number of civil society organizations have made decent contributions thanks to foreign support, with the Open Society Foundation as one prominent example.

\section{CHANGING GENERATION AND OUTLOOK}

One additional factor has to be mentioned: the generation shift. Nigeria has a young population after years of high population growth. There is a 
youth bulge, with more than 13 million first-time voters in 2015. With sky-high youth unemployment and few young people seeing benefits from the oil-rich government's patronage spending, and with widespread political mobilization through social media, the Internet and pop culture, most of the young vote went to the opposition and contributed to the political shift (Nwosu 2015; NDI 2015; Johnson 2015).

\section{THE ONLY GAME IN TOWN}

Although Nigeria has yet to be a consolidated democracy with two elections leading to a change in government, there is now greater respect for democratic rules and institutions. Democracy seems to have gained a foothold as the 'only game in town'. In the words of one voter to a journalist (The Economist 2015): 'If things are not better with Buhari, we will get rid of him in four years' time.'

\section{REFERENCES}

ACET. 2014. 2014 African Transformation Report: Growth with Depth. African Center for Economic Transformation. Accra.

Amundsen, I. 2010. Good Governance in Nigeria: A Study in Political Economy and Donor Support. Norad Discussion Report 17/2010. Norad. Oslo.

Amundsen, I. 2014. 'Drowning in oil: Angola's institutions and the "resource curse". Comparative Politics, 46(1), 169-189.

Andersen, J.J. and Aslaksen, S. 2013. 'Oil and political survival'. Journal of Development Economics, 100, 89-106.

Andersen, J.J. and Ross, M.L. 2014. 'The big oil change. a closer look at the Haber-Menaldo analysis'. Comparative Political Studies, 47(7), 993-1021.

Auty, R.M. 1993. Sustaining Development in the Mineral Economies: The Resource Curse Thesis. Routledge. London.

Collier, P. and Hoeffler, A. 2001. Greed and Grievance in Civil War. The World Bank. Washington, DC.

Edozien, F. 2015. 'Nigeria's Jonathan doesn't need good luck for votes in his Delta region stronghold'. Quartz blog-post 17 March: http://qz.com/364283/ nigerias-jonathan-doesnt-need-good-luck-for-votes-in-his-delta-region-stronghold/ (accessed 23 January 2016).

Gboyega, A., Søreide, T., Minh Le, T. and Shukla, G.P. 2011. Political Economy of the Petroleum Sector in Nigeria. Policy Research Working Paper 5779. The World Bank. Washington, DC.

Goldfond, J. 2015. 'Nigeria's resource curse: Boko Haram and the poverty of plenty'. Open Democracy website, 8 April 2015: www.opendemocracy.net/ joshua-goldfond/nigeria\%E2\%80\%99s-resource-curse-boko-haram-and-povertyof-plenty (accessed 27 August 2015). 
Gylfason, T. 2001. 'Natural resources, education, and economic development'. European Economic Review, 45(4-6), 847-859.

Heller, T.C. 2006. 'African transitions and the resource curse: an alternative perspective'. Economic Affairs, 26(December), 24-33.

HRW. 2005. Rivers and Blood: Guns, Oil and Power in Nigeria's Rivers State. Briefing Paper, February 2005. Human Rights Watch (HRW). New York.

HRW. 2011. Corruption on Trial? The Record of Nigeria's Economic and Financial Crimes Commission. Report, 25 August 2011. Human Rights Watch (HRW). New York.

Humphreys, M., Sachs, J.D. and Stiglitz, J.E. 2007. Escaping the Resource Curse. Columbia University Press. New York.

International Crisis Group. 2014. 'Curbing violence in Nigeria (II): the Boko Haram insurgency'. ICG Africa Report, No 216, 3 April. International Crisis Group (ICG). Brussels.

Johnson, O. 2015. 'The role of social media in the 2015 presidential elections in Nigeria'. Voices of Youth web post: www.voicesofyouth.org/en/posts/therole-of-social-media-in-the-2015-presidential-elections-in-nigeria (accessed 23 January 2016).

Mähler, A. 2010. Nigeria: A Prime Example of the Resource Curse? Revisiting the Oil-Violence Link in the Niger Delta. GIGA WP 120/2010. German Institute of Global and Area Studies (GIGA). Hamburg.

Mehlum, H., Moene, K. and Torvik, R. 2006. 'Cursed by resources or institutions?' The World Economy, 29(August), 1117-1131.

National Bureau of Statistics, Republic of Nigeria. National statistics downloadable at the data portal: www.nigerianstat.gov.ng/ (accessed 26 August 2015). See also BBC World News 13 February 2012: www.bbc.com/news/worldafrica-17015873 (accessed 9 August 2016).

NDI. 2015. Statement of the National Democratic Institute's International Observer Mission to Nigeria's March 28 Presidential and Legislative Elections. Report. National Democratic Institute (NDI). Washington, DC: www.ndi.org/nigeria-election-observation-statement-march-2015 (accessed 23 January 2016).

Nwosu, C. 2015. 'Nigeria's youth factor'. Foreign Policy in Focus, news: http://fpif.org/nigerias-youth-factor/ (accessed 23 January 2016).

Robinson, J.A., Torvik, R. and Verdier, T. 2005. 'Political foundations of the resource curse'. Journal of Development Economics, 79(February), 447-468.

Ross, M.L. 2001. 'Does oil hinder democracy?' World Politics, 53, 325-361.

Ross, M.L. 2012. The Oil Curse: How Petroleum Wealth Shapes the Development of Nations. Princeton University Press. Princeton, NJ.

Sachs, J.D. and Warner, A.M. 2001. 'The curse of natural resources'. European Economic Review, 45(May), 827-838.

SaharaReporters. 2015. MEND Endorses Buhari for President, Says Voting Jonathan is Biggest Mistake Niger Deltans Ever Made. New York, 6 January 2015: http://saharareporters.com/2015/01/06/mend-endorses-buhari-presidentsays-voting-jonathan-biggest-mistake-niger-deltans-ever (accessed 24 January 2016).

Shaxson, N. 2007. Poisoned Wells. The Dirty Politics of African Oil. Palgrave Macmillan. New York. 
Soares de Oliveira, R. 2007. Oil and Politics in the Gulf of Guinea. Hurst and Company. London.

The Economist. 2015. 'Nigeria's election: hail to democracy'. The Economist, 4 April, print edition. London.

TI. 2004. Press Release: Global Corruption Report 2004, 25 March. Transparency International (TI). Berlin.

TI. 2009. Global Corruption Report 2009. Transparency International (TI). Berlin.

Usman, Z. 2014. 'The political economy of economic diversification in Nigeria'. Paper presented to the 14th EADI General Conference: Responsible Development in a Polycentric World. University of Oxford. Bonn.

Watts, M. 2004. 'Resource curse? Governmentality, oil and power in the Niger delta, Nigeria'. Geopolitics, 9(1), 50-80.

World Bank. 1999. Nigeria - Country Procurement Assessment Report (CPAR). The World Bank. Washington, DC.

World Bank Institute. 2013. Worldwide Governance Indicators. Interactive dataset. World Bank Institute (WBI). Washington, DC: http://info.worldbank. org/governance/wgi/index.aspx (accessed 27 August 2015). 